\title{
Hidroksiüre'nin Neden Olduğu Longitidunal Melanonişi
}

\author{
Longitudinal Melanonychia Caused by Hydroxyurea
}

\author{
Göknur KALKAN ${ }^{1}$, Zennure TAKCl${ }^{2}$, Özlem TEKIN² \\ ${ }^{1}$ Gaziosmanpaşa Üniversitesi Tıp Fakültesi, Dermatoloji AD, Tokat \\ ${ }^{2}$ Sağlık Bakanlığı Keçiören Eğitim Araştırma Hastanesi, Deri ve Zührevi Hastalıklar Kliniği, Ankara
}

\section{ÖZET}

Hidroksiüre, miyeloproliferatif hastalıkların tedavisinde kullanılan sitostatik bir kemoterapotik bir ajandır. Uzun dönem tedavide mukokütanöz yan etkiler ve trnak pigmentasyonu görülebilmektedir. Hidroxiürenin indüklediği melanonişi, en çok kadınlarda en sık olarak da longitidunal çizgilenme şeklinde görülür. Burada polisitemia rubra vera tanısıyla hidroksiüre kullanan, tedavisinin 18. ayında el parmak tırnaklarında longitudinal melanonişi ortaya çıkan 65 yaşında kadın hasta sunulmuştur. Bu vakadan hareketle, miyeloproliferatif hastalıklarda ve orak hücreli aneminin tedavisinde kullanımı gittikçe yaygınlaşan hidroksiürenin çok sayıdaki kutanöz yan etkilerinin farkında olunması amaçlanmıştır.

Anahtar Kelimeler: Hidroksiüre, melanonişi, polisitemi vera

\section{ABSTRACT}

Hydroxyurea is a chemotherapeutic agent which is used in the management of myeloproliferative disorders. Mucocutaneous adverse effects and nail hyperpigmentation can be observed in long-term treatment. Cases of hydroxyurea-induced melanonychia develop predominantly in female patients and the most common pattern is longitudinal bands. Here we present a case of 65-year-old woman patient that has longitudinal melanonychia on the nails of the hands, observed at the eighteenth month of the treatment of hydroxyurea. By means of this case, it is aimed to be aware of the cutaneous side effects of hydroxyurea which is commonly used in myeloproliferative disorders.

Keywords: Hydroxyurea; melanonychia, polycythemia vera

\section{Giriş}

Melanonişi, enfeksiyonlar, bazı sistemik hastalıklar, metabolik bozukluklar, melanositik ve ekzojen nedenler ve belirli ilaçların tırnak plağında depolanması ile ortaya çıkabilir (1). Hidroksiüre, kronik myelositik lösemi, polisitemia vera ve esansiyel trombositemi gibi miyeloproliferatif hastalıkların tedavisinde kullanılan sitostatik bir kemoterapötik bir ajandır (2). Uzun dönem tedavide mukokütanöz yan etkiler ve trnak pigmentasyonu görülebilmektedir.

Yazışma Adresi / Correspondence: Göknur Kalkan Adres: Gaziosmanpaşa Üniversitesi Tıp Fakültesi, Dermatoloji Anabilim Dalı, Tokat 60100

e-mail: goknurkalkan@yahoo.com
Hidroksiürenin indüklediği melanonişi vakaları nadir olarak görülmektedir (1-3). Burada polisitemia rubra vera tanısıyla 3 yıldır 1500 mg/gün hidroksiüre kullanan, tedavisinin 18. ayında el parmak tırnaklarında longitudinal melanonişi ortaya çıkan 65 yaşında kadın hasta sunulmuştur.

\section{OLGU SUNUMU}

Altmış beş yaşında kadın hasta el parmak tırnaklarında renk değişikliği şikayetiyle polikliniğimize başvurdu. Hastanın sorgulamasında 3 yıldır polisitemi vera tanısıyla 1500 mg/gün hidroksiüre kullandığı öğrenildi. Tedavinin başlanmasından yaklaşık 1,5 yıl sonra el parmak trnaklarında kahverengi bant tarzında renk değişikliklerinin başladığını ifade eden hastanın 
bilinen farklı sistemik hastalık öyküsü ve sürekli kullandığı ilacı yoktu. Dermatolojik muayenede el parmak tırnaklarında proksimal trrnak kıvrımından başlayarak tırnak distaline kadar uzanan kahverengi longitudinal melanonişi bantları görüldü (Şekil 1, 2, 3). Deride, mukozal yüzeylerde, dişlerde ve sklerada pigmentasyon saptanmadı.
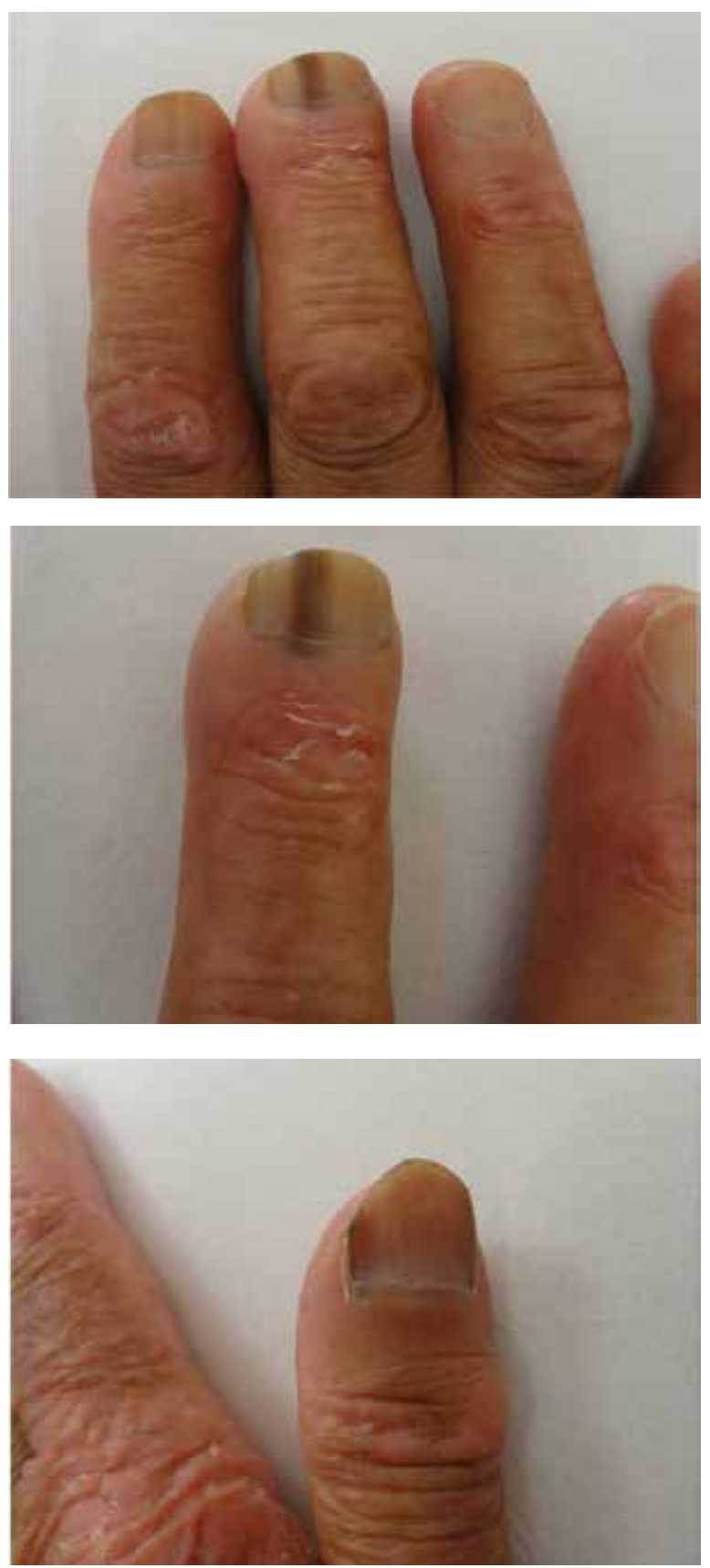

Şekil 1,2,3: El parmak tırnaklarında longitudinal melanonişi.

\section{TARTIŞMA}

Hidroksiüre selüler replikasyon sırasında, S fazına etki eden, DNA sentezini inhibe eden, ancak RNA sentezini etkilemeyen sitostatik bir ajandır. Kronik miyeloproliferatif hastalıkların tedavisinde 40 yıldır kullanılmaktadır (4). Genelde iyi tolere edilmesine rağmen, deri, müköz membran ve tornaklarda bir takım değişikliklere yol açabilir. Bildirilen mukokütanöz yan etkiler: pigmentasyon artşı, hiperkeratoz, deri atrofisi, kserozis, likenoid erüpsiyonlar, palmoplantar keratoderma, kutanöz vaskülit, alopesi, melanonişi, kronik bacak ülserleri ve kutanöz karsinomlardır. Uzun dönem tedavi sonrası dermatomiyozit benzeri erüpsiyon, oral ülserler, stomatit, orofaringeal mukozada hiperpigmentasyon gibi mukozal değişiklikler de görülmüştür. Hidroksiüre ile indüklenen trnak bozuklukları; onikoliz, onikodistrofi, kırılgan atrofik trnaklar, onikoşizi ve melanonişidir $(5,6)$.

Hidroksiürenin indüklediği melanonişi, tedavinin başlangıcından sonra en erken 8 hafta, en geç 5 yıl sonra görülebilir. Kadınların \%4'ünde, sıklıkla da longitudinal bantlar şeklinde gözlenir. $(1,3,5)$. Koley ve ark.'nın bildirdikleri vakada hidroksiüre tedavisini takiben 10 hafta içinde baş parmakları dışında tüm tırnaklarda (7), Utaş ve ark.'nın bildirdikleri vakada ise 8 hafta sonra, 20 trrnakta longitidunal melanonişi gözlenmiştir (8). Buradaki kadın hastada tedavinin başlanmasından yaklaşık 1,5 yıl sonra el parmak tırnaklarında en sık görülen longitudinal melanonişi paterni gözlenmiştir.

Anti-neoplastik ilaçlar nedeniyle olan trnak değişiklikleri asemptomatiktir ve ajanın kesilmesini takiben tamamen geri dönüşümlüdür. Antineoplastik ilaçlarla en sık olarak gözlenen tırnak değişikliği olan melanonişi; difüz, transvers ve longitidunal paternde olmaktadır. Eş zamanlı deride melanoderma olarak adlandırılan difüz pigmentasyon gözlenebilir. Hidroksiürenin indüklediği melanonişinin mekanizması tam olarak aydınlatılmamıştır; genetik predispozisyon, trnak yatağı veya matriksini etkileyen toksisite, trnak matriksinin fokal uyarılması, melanositler ve fotosensitizasyon olabileceği düşünülmektedir $(3,8)$. Ayırıcı tanıda, subungual melanom, subungual hematom, pigmente skuamöz hücreli karsinom, trrnak matriks melanositik nevüsü, lentigo ve lentigonun diğer tipleri, diğer ilaçlarla olan hiperpigmentasyon (siklofosfamid, doksorubasin, minosiklin ve zidovudin 
gibi), etnik tirnak pigmentasyonu, tekrarlayan travmanın indüklediği pigmentasyon ve subungual hemorajiler yer alır (7-9).

Bu konuda yayınlanan literatürler tarandığında; yakın zamanda Şili'den bildirilen bir çalışmada esansiyel trombositemi nedeniyle hidroksiüre ile tedavi edilen 7 vakada gelişen melanonişi olgusunun \%26'sında, 2-7 yıl sonra dozdan bağımsız olarak melanonişi geliştiği belirtilmiştir (10). Melanonişinin yüksek oranda görülmesini; İspanyolların koyu esmer ırkları nedeniyle veya maruz kalınan yüksek UV ışınlar nedeniyle olabileceği düşünülmektedir. Bu konuda 9 hastalık Aste ve arkadaşları tarafindan bildirilen seride; hidroksiüre tedavi dozu veya süresinden bağımsız her 2 el ve ayaktaki tırnakları eşit olarak etkilemiş, diğer deri değişiklikleri ile ilişkili olabilmiş ve en sık longitudinal melanonişi gözlenmiştir (3).

Longitudinal melanonişi özellikle tek tırnakta ise, melanom olasılığını ekarte etmek için biyopsi yapmak gerekir. Özellikle longitudinal melanonişi ve periungual hiperpigmentasyon beraber görüldüğünde melanomdaki Hutchinson işareti ile karışabilmektedir (1,11). Dozu azaltmak veya tedaviyi kesmek, melanonişiyi zamanla azaltsa da, altta yatan miyeloproliferasyonun kronik süreci ve tedavi seçeneklerinin azlığı, tedavi değişikliği yapmayı zorlaştırmaktadır (10). Klinik direnç veya tedaviye intolerans gelişmedikçe, esansiyel trombositozlu hastalarda, bu yan etkinin tedaviyi kesmeyi gerektiren bir yan etki olmadığı düşünülmektedir. Ancak deri ülserasyonu veya karsinoma gelişimi gibi daha ciddi mukokütanöz bir yan etkiye öncülük etmesi açısından önem arz etmektedir (12). Miyeloproliferatif hastalıklarda ve orak hücreli aneminin tedavisinde hidroksiüre kullanımı yaygınlaşt̆ğından, doktorların bu ilacın çok sayıdaki kutanöz yan etkilerinin farkında olmaları amacıyla bu olgu sunulmuştur.

\section{Kaynaklar:}

1. Ceulen RP, Frank J, Poblete-Gutiérrez P. Nail pigmentation due to hydroxycarbamide. Int J Dermatol 2007;46(3):13-5.

2. Joyner $S$, Lee $D$, Hay $P$, et al. Hydroxyurea-induced nail pigmentation in HIV patients. HIV Med 1999;1(1):40-2.

3. Aste N, Fumo G, Contu F, et al. Nail pigmentation caused by hydroxyurea: report of 9 cases. J Am Acad Dermatol 2002;47(1):146-7.

4. Sirieix ME, Debure $C, B a u d o t ~ N$, et al. Leg ulcers and hydroxyurea. Arch Dermatol 1999; 135(7): 818-20.

5. Issaivanan M, Mitu PS, Chakrabarti M, et al. Cutaneous manifestations of hydroxyurea therapy in childhood: case report and review. Pediatr Dermatol 2004; 21(2):124-7.

6. Oh ST, Lee DW, Lee JY, et al. Hydroxyurea-induced melanonychia concomitant with a dermatomyositislike eruption. J Am Acad Dermatol 2003; 49 (2):33941.

7. Koley S, Choudhary S, Salodkar A. Melanonychia and skin hyperpigmentation with hydroxyurea therapy. Indian J Pharmacol 2010;42(1):60-1.

8. Utaş S, Kulluk P. A case of hydroxyureainduced longitudinal melanonychia. Int J Dermatol 2010;49(4):469-70.

9. Thomas L, Dalle S. Dermoscopy provides useful information for the management of melanonychia striata. Dermatol Ther 2007; 20(1): 3-10.

10. Murray NP, Tapia P, Porcell J, et al. Acquired melanonychia in chilean patients with essential thrombocythemia treated with hydroxyurea: a report of 7 clinical cases and review of the literature. ISRN Dermatol 2013;2013:325246. doi: 10.1155/2013/325246. Epub 2013 Feb 7.

11. Thai KE, Young R, Sinclair RD. Nail apparatus melanoma. Australas J Dermatol 2001;42(2):71-81.

12. Wiechert A, Reinhard G, Tuting $T$, et al. Multiple skin cancers in a patient treated with hydroxyurea. Hautarzt 2009;60(8):651-4. 
